\title{
RESTRAINING EFFECTS OF THE FINAL JUDGMENT RULE ON THE ARBITRATION PROCESS
}

With the passage of the Federal Arbitration Act ${ }^{1}$ Congress indorsed the use of arbitration as a speedy and inexpensive method of settling controversies. ${ }^{2}$ Arbitration agreements, unenforceable at common law, ${ }^{3}$ have been made valid

1. 9 U.S.C. $\$ \$ 1-14$ (1952).

2. "[T] $T$ here is so much agitation against the costliness and delay of litigation. These matters can be largely eliminated by agreements for arbitration, if arbitration agreements are made valid and enforceable." H.R. Rep. No. 96, 68th Cong., 1st Sess. 2 (1923). See also Robb, Arbitration Procedure Compared with Court Litigation in Patent Controversies, 17 Law \& Contrarp. Prob. 679 (1952); Sturges, Commercial Arbitration or Coutr Application of Common Law Rules of Marketing, 34 YaLE I.J. 480 (1925); Note, 61 HaRv. L. REv. 1022 (1948).

Other advantages of arbitration include: (1) use of experts to resolve questions of business fact and trade usage, Comment, 61 YALE L.J. 686, 708-09 (1952); (2) avoidance of the publicity usually incident to proceedings in a court, Grossman, Arbitration and the Lawyer, 17 N.Y.U.L.Q. REv. 511, 514 (1940); (3) a "friendlier" forum than an adversary litigation, Taeusch, Extrajudicial Settlement of Controversies, 83 U. PA. L. REv. 147, 151 (1934); (4) less strict adherence to technical rules of evidence, Mentschikoff, The Significanic of Arbitration-A Preliminary Inquiry, 17 LAW \& CONTEMr. PROB. 698, 704 (1952). Further, arbitration agreements often help prevent disputes since the parties know that disputes solely for delay will be settled quickly and hence ineffective. Baum \& Pressman, The Enforcement of Commercial Arbitration Agreements in the Federal Courts, S N.Y.U.L.Q. REv. 238, 250 (1930).

For indications of congressional approval of arbitration, see, e.g., Agostini Bros. Bldg. Corp. v. United States ex rel. Virginia-Carolina Elec. Works, 142 F.2d 854, 855 (4th Cir. 1944) ; Kulukundis Shipping Co. v. Amtorg Trading Corp., 126 F.2d 978, 985 n.24a (2d Cir. 1942); Stathatos v. Arnold Bernstein S.S. Corp., 202 F.2d 525, 528 (2d Cir. 1953) (dissenting opinion).

3. At common law, an agreement to arbitrate was revocable at any time before the arbitration award. United States Asphalt Refining Co. v. Trinidad Lake Petroleum Co., 222 Fed. 1006 (C.C.S.D.N.Y. 1915) ; Meachem v. Jamestown F. \& C.R.R., 211 N.Y. 346, 105 N.E. 653 (1914); see Kulukundis Shipping Co. v. Amtorg Trading Corp., 126 F.2d 978 (2d Cir. 1942), giving historical background of revocability doctrine. See, generally, Sturges, Commercial Arbitrations and Awards $\$ 15$ (1930) (hereinafter cited as StURGes) ; Jones, Historical Development of Commercial Arbitration in the United States, 12 Minn. L. Rev. 240 (1927) ; Sayre, Development of Commercial Arbitration Laze, 37 YALE L.J. 595 (1924).

Breach of a common law agreement to arbitrate would result only in nominal damages, if any. Munson v. Straits of Dover S.S. Co., 99 Fed. 787 (C.C.S.D.N.Y. 1900) ; Cocalis v. Nazilides, 308 Ill. 152, 139 N.E. 95 (1923); Sturges $\S 22$. But the power to revoke was extinguished when an award was duly rendered. Buckwalter v. Russel, $119 \mathrm{~Pa}$. 495, 13 Atl. 310 (1888); cf. Roberts, Johnson, \& Rand Shoe Co. v. Westinghouse Elec. \& Mfg. Co., 143 Fed. 218 (C.C. Mo. 1906) ; Lesser v. Pallay, 96 Ore. 142, 188 Pac. 718 (1920).

Because of the revocability doctrine, a court would not specifically enforce an arbitration agreement nor recognize it as a bar to a suit on the contract containing the arbitration 
and irrevocable. ${ }^{4}$ Summary motion practice under sections $3^{5}$ and $4^{6}$ of the act allows a party to secure a court order staying judicial proceedings and

clause. Specific performance denied: Red Cross Line v. Atlantic Fruit Co., 264 U.S. 109, 121 (1924); Restatenent, Contracts $\$ 550$ (1932); see Simpson, Specific Enforcentent of Arbitration Contracts, 83 U. PA. L. Rev. 160 (1934). Stay of pending suit denied: Insurance Co. v. Morse, 87 U.S. (20 Wall.) 445, 451 (1874) (dictum). Institution af a suit by a party to an arbitration agreement revokes the agreement. Bullock v. Mason, 194 Ala. 663,69 So. 882 (1915).

These rules applied both to arbitration agreements covering future controversies (future disputes clauses) and agreements which submitted existing controversies to arbitration (submission agreements). See STurges $\$ 67$.

4. "A written provision in any maritime transaction or a contract evidencing a transaction involving commerce to settle by arbitration a controversy . . . shall be valid, irrevocable, and enforceable, save upon such grounds as exist at law or in equity for the revocation of any contract."

9 U.S.C. $\$ 2$ (1952).

By eliminating the doctrine of revocability, the act placed arbitration agreements on the same footing as other contracts. See H.R. REP. No. 96, 68th Cong., 1st Sess. (1923); S. REP. No. 536, 68th Cong., 1st Sess. (1923). The act may not be invoked to enforce an arbitration agreement unless the contract containing the agreement qualifies under $\S 2$. Bernhardt v. Polygraphic Co. of America, 350 U.S. 198 (1956) (stay provided in $\$ 3$ reaches only contracts covered by $\$ \$ 1$ and 2 ). Therefore, the enforceability of an arbitration agreement which does not involve a maritime or interstate commerce transaction will be determined in a federal court by state law. Id. at 207; Tejas Development Co. v. McGaugh Bros., 165 F.2d 276 (5th Cir. 1948).

Forty-two states have also passed modern arbitration statutes. See Note, 56 CoLun. L. Rev. 902, 903 n.8 (1956). Those statutes which follow the New York type of legislation, like the Federal Arbitration Act, provide that agreements to arbitrate both present and future disputes are irrevocable. Other statutes grant irrevocability only to submission agreements. Id. at $903,904$.

5. "If any suit or proceeding be brought in any of the courts of the United States upon any issue referable to arbitration under an agreement in writing for such arbitration the court in which such suit is pending, upon being satisfied that the issue involved in such suit ... is referable to arbitration under such an agrcement, shall on application of one of the parties stay the trial of the action until . . arbitration has been had ... providing the applicant for the stay is not in default in proceeding with such arbitration."

9 U.S.C. $\$ 3$ (1952).

Even if an issue is referrable to arbitration under a contract, the court may deny a stay if it decides the moving party is in "default" and has thus waived his right to a stay. American Locomotive Co. v. Chemical Research Corp., 171 F.2d 115 (6th Cir. 194ki. Since the act is designed to expedite settlement of disputes, a party who is dilatory in his request for a stay may not claim the benefits of the statute. Radiator Specialty Co. v. Cannon Mills, 97 F.2d 318 (4th Cir. 1938) ; Cargo Carriers, Inc. v. Erie \& St. Lawrence Corp., 105 F. Supp. 638 (W.D.N.Y. 1952) (dissolution of stay order because party failed to intitiate steps to secure arbitration).

6. "A party aggrieved by the alleged failure, neglect, or refusal of another to arbitrate under a written agreement for arbitration may petition any United States District Court ... for an order directing that such arbitration procced in the manner pruvided for in such agreement.... [If the court is] satisfied that the making of the 
specifically enforcing the arbitration agreement. ${ }^{7}$ However, the policy which led to passage of the Arbitration Act is in large measure undercut by the final judgment rule of federal appellate procedure. In order to make best use of the advantages arbitration offers, court orders determining whether a dispute is arbitrable should be immediately appealable. Otherwise, reversal of an erroneous trial court order will mean that a trial following denial of arbitration or arbitration improperly granted will be entirely wasted. But with few exceptions, ${ }^{8}$ federal procedure allows appeals only from "final judgments" on the theory that interlocutory appeals are generally disruptive of litigation, expensive and

agreement for arbitration or the failure to comply therewith is not in issue, the court shall make an order directing the parties to proceed to arbitration in accordance with the terms of the agreement ...."

o U.S.C. $\$ 4$, as amended, 9 U.S.C. $\$ 4$ (Supp. III 1956). See The Anaconda v. American Sugar Refining Co., 322 U.S. 42 (1944); Marine Transit Corp. v. Dreyfus, 284 U.S. 263, 278 (1932) ; Albatross S.S. Co. v. Manning Bros., 95 F. Supp. 459 (S.D.N.Y. 1951).

Issuance of an order compelling arbitration pursuant to $\S 4$ is dependent upon the court's finding that (1) the making of a valid arbitration agreement and (2) the failure to comply therewith are not in issue. Should the court decide a dispute exists as to these requirements, it will either summarily try the issues or, upon demand by the party allegedly in breach, refer the issues to a jury. Should the jury or the court determine the statutory conditions to the operation of $\S 4$ are satisfied, the court will order arbitration. John Thompson Beacon Windows, Ltd. v. Ferro, Inc., 232 F.2d 366 (D.C. Cir. 1956) (dictum; appeal dismissed on procedural grounds). However, even if the statutory provisions are met, the court may not order arbitration if the defaulting party alleges a legal defense, such as the statute of limitations or illegality, which would make the agreement unenforceable on contract grounds. Kulukundis Shipping Co. v. Amtorg Trading Corp., 126 F.2d 978 (2d Cir. 1942); Goldhill Trading \& Shipping Co., S.A. Panama v. Caribbean Shipping Co., 56 F. Supp. 31 (S.D.N.Y. 1944). Courts may also refuse specific performance through the use of equitable discretion. RFC v. Harrisons \& Crosfield, 204 F.2d 366, 369-70 (2d Cir. 1953). See Comment, 21 U. CHI. L. Rev. 719 (1954).

See, generally, Phillips, The Paradox in Arbitration Law; Compulsion as Applied to a Voluntary Praceeding, 46 HARv. L. Rev. 1258 (1933); Platt, et. al., The United States Arbitration Laz and Its Application, 11 A.B.A.J. 153 (1925).

7. "Any application to the court hereunder shall be made and heard in the manner provided by law for the making and hearing of motions, except as otherwise herein expressly provided." 9 U.S.C. \& 6 (1952).

8. Interlocutory orders made appealable by statute include the following: (1) grant or refusal of an injunction; (2) the appointment of receivers; (3) determination of the rights and liabilities of parties in admiralty cases; (4) judgment in civil actions for patent infringement which are final except for an accounting. 28 U.S.C. $\S 1292$ (1952).

See, generally, 6 Moore, Feneral Practice $\$ 54.12$ (2d ed. 1953) (hereinafter cited as MOORE).

9. The final judgment rule is codified in 28 U.S.C. $\$ 1291$ (1952). A final judgment ands litigation on the merits and leaves nothing for the court to do but execute judgment. Catlin v. United States, 324 U.S. 229 (1945); $c f$. Cobbledick v. United States, 309 U.S. 323 (1940). See, generally, 6 MIOORE $\$ 54.11$; Crick, The Final Judgment as a Basis for Appial, 41 Yate L.J. 539 (1932).

Appeals from orders concerning arbitration are governed by the Federal Rules of Civil Procedure. Fed. R. CIv. P. 81 (a) (3). 
time-consuming. ${ }^{10}$ Thus orders granting or denying arbitration are appealable only if the requirements of appellate practice are met. Consequently, although the need for immediate appeal is the same in each case, the result will vary with the procedural context in which the order is made.

Because orders on motions to compel arbitration are governed by the final judgment rule, appealability depends initially on whether the motion is made in an independent proceeding or in the course of a suit. If a motion to compel arbitration is made in an independent proceeding under section 4 , an order of the court granting or denying the motion is characterized as a final judgment and thereby appealable. ${ }^{11}$ The court takes jurisdiction only to determine whether it should compel performance of the arbitration agreement. ${ }^{12}$ An order denying the motion to compel arbitration is a final judgment since it terminates an independent proceeding and is equivalent to dismissal of the action. ${ }^{13}$ If the motion is granted, the court order is the "last deliberative act of the court"14 and is thus also considered a final judgment. ${ }^{15}$

10. Rexford v. Brunswick-Balke-Collender Co., 228 U.S. 339 (1913); McLish v. Roff, 141 U.S. 661 (1891).

Besides the factors of expense and delay, other reasons cited are that nonappealability of interlocutory orders (1) expedites judicial business by preventing appeal from erroneous orders which may later prove harmless, In re Chappel \& Co., 201 F.2d 343, 345 (1st Cir. 1953); (2) in conformity with the Federal Rules of Civil Procedure, eliminates emphasis on pure points of procedure, Audi Vision Inc. v. RCA Mfg. Co., 136 F.2d 621, 625 (2d Cir. 1943) ; (3) provides uniformity and certainty of judicial administration for litigants, cf. Cobbledick v. United States, 309 U.S. 323 (1940). The final judgment rule has been extensively criticized, particularly on the charge that the unappealability of certain interlocutory orders may cause irreparable harm to the parties. See Audi Vision v. RCA Mfg. Co., supra at 625-28 (concurring opinion); Note, 58 YALE L.J. 1186, 1187 (1949); 6 MOORE \& 54.43[4].

11. Goodall-Sanford, Inc. v. Local 1802, United Textile Workers, AFL, 233 F.2d 104 (1st Cir. 1956), cert. granted, 25 U.S.L. WEEK 3104 (U.S. Oct. 8, 1956) (No. 262); American Locomotive Co. v. Gyro Process Co., 185 F.2d 316 (6th Cir. 1950) ; Continental Grain Co. v. Dant \& Russel, Inc., 118 F.2d 967 (9th Cir. 1941), Contra, Stathatos v. Arnold Bernstein S.S. Corp., 202 F.2d 525 (2d Cir. 1953).

12. Continental Grain Co. v. Dant \& Russel, Inc., 118 F.2d 907 (9th Cir. 1941); Krauss Bros. Lumber Co. v. Louis Bossert \& Sons, Inc., 62 F.2d 1004 (2d Cir. 1933).

13. Fremont Cake \& Meal Co. v. Wilson \& Co., 183 F.2d 57 (8th Cir. 1950) (appealability assumed without discussion). A court order dismissing an action on the merits is a final judgment. Sosa v. Royal Bank of Canada, 134 F.2d 955 (1st Cir. 1943).

14. Krauss Bros. Lumber Co. v. Louis Bossert \& Sons, Inc., 62 F.2d 1004, 1005 (2d Cir. 1933) (motions granted to compel arbitration and appoint arbitrators). The court order compelling arbitration gives jurisdiction over the controversy to the arbitrators. Ibid. The court retains jurisdiction to enter judgment on the award. Cf. Evans v. Hudson Coal Co., 84 F. Supp. 740 (M.D. Pa. 1949) (after issuance of stay, court was without jurisdiction to compel party to produce documents). Where the parties provide in their agreement for entry of judgment on the award, judgment and execution are automatic under $\$ \$ 9$ and 13 of the act unless the award is vacated under the provisions of $\$ 10$. Kraus Bros. Lumber Co. v. Louis Bossert \& Sons, Inc., supra. If the arbitration agreement contains no express stipulation for entry of judgment, a separate action on the award is necessary. Continental Grain Co. v. Dant \& Russel, Inc., 118 F.2d 967 (9th Cir. 1941) ; Lehigh Structural Steel Co. v. Rust Engineering Co., 59 F.2d 1038 (D.C. Cir. 1932).

15. Canadian Gulf Line, Ltd. v. Continental Grain Co., 98 F.2d 711 (2d Cir. 1938); 
When entered in the course of a suit on the contract, a motion to compel arbitration is almost uniformly joined with a motion to stay the court action. The court may pass upon the motions separately. ${ }^{16}$ In that case, its decision on the motion to compel will be appealable if considered analogous to a motion made in a separate proceeding. ${ }^{17}$ On the other hand, if the motion is viewed as made in the course of the suit, an order on the motion would probably be deemed an unappealable interlocutory order. This was the conclusion in the single case treating the issue. ${ }^{18}$ But since the decision was in admiralty where courts do not grant injunctions, ${ }^{19}$ the court could not pass on whether the order could be interpreted as an appealable injunctive decree, a statutory exception to the final judgment rule. ${ }^{20}$

Courts may find a sufficient injunctive effect to allow appeal when ruling on the motion to stay the pending suit. When based on the stay motion, the order will be considered an injunction only if the original action on the contract is brought in law. ${ }^{21} \mathrm{~A}$ special defense setting up an arbitration agreement as the basis for motions to stay and compel arbitration is equitable in nature. ${ }^{22}$ Consequently, if the motions are made in an action at law, the court's order

The Sydfold, 25 F. Supp. 662 (S.D.N.Y. 1938) (costs granted for $\$ 4$ proceeding since order compelling arbitration is final judgment). A $\S 4$ proceeding is completed upon the grant of the only relief sought, an order compelling arbitration; the order is thus final in the sense of 28 U.S.C. $\$ 1291$ (1952). Goodall-Sanford, Inc. v. Local 1802, United Textile Workers, AFL, 233 F.2d 104 (1st Cir. 1956), cert. granted, 25 U.S.L. WeEk 3104 (U.S. Oct. 8, 1956) (No. 262). The contrary decision in Stathatos v. Arnold Bernstein S.S. Corp., 202 F.2d 525 (2d Cir. 1953) (motions vacating award and resubmitting case to arbitration), may perhaps be explained by Judge Charles E. Clark's general opposition to appeals which appear interlocutory. See Zalkind v. Scheinman, 139 F.2d 895, 905 (2d Cir. 1943) (dissenting opinion), cert. denied, 322 U.S. 738 (1944); Audi Vision Inc. v. RCA Mfg. Co., 136 F.2d 621 (2d Cir. 1943); Clark, Code Pleading \$§ 18, 84 n.104 (1947).

16. The prior refusal to stay proceedings under $\$ 3$ will not be considered a bar to the later motion to compel arbitration. American Locomotive Co. v. Gyro Process Co., 185 F.2d 316, 318 (6th Cir. 1950).

17. Id. at 317-18. La Nacional Platanera, S.C.L. v. North Carolina Fruit \& S.S. Corp., S4 F.2d 881 (5th Cir. 1936).

18. In re Pahlberg, 131 F.2d 968 (2d Cir. 1942). See discussion in Stathatos v. Arnold Bernstein S.S. Corp., 202 F.2d 525, 528 (2d Cir. 1953) (dissenting opinion).

19. Schoenamsgruber v. Hamburg American Line, 294 U.S. 454 (1935); DiaconZadeh v. Denizyollari, 196 F.2d 491 (3d Cir. 1952). See Robinson, Arbitration in Admiralty, 17 N.Y.U.L.Q. REv. 573, 580 (1940). Admiralty courts only issue injunctions in limitation of liability proceedings where they are given general equitable power by statute. See, generally, 46 U.S.C. $\$$ 183-89 (1952); Schoenamsgruber v. Hamburg American Line, supra at 457-58.

20. 28 U.S.C. \& 1292 (1952).

21. Shanferoke Coal \& Supply Co. v. Westchester Serv. Co., 293 U.S. 449 (1935); American Locomotive Co. v. Chemical Research Corp., 171 F.2d 115 (6th Cir.), cert. denied, 336 U.S. 909 (1948); Gatliff Coal Co. v. Fox, 142 F.2d 876 (6th Cir. 1947).

22. Shanferoke Coal \& Supply Co. v. Westchester Serv. Co., 293 U.S. 449, 452 (1935). 
is considered analogous to an equity court's action enjoining or refusing to enjoin proceedings in a court of law; the order is appealable as a decision on an interlocutary injunction. ${ }^{23}$ A decision on the motion is unappealable if the original suit is in equity. ${ }^{24}$ The order in this instance is deemed only an exercise of a court's inherent power to control the course of proceedings within the framework of a suit before it. ${ }^{25}$

In any situation, therefore, orders concerning arbitration are appealable only if they fit by chance into a historical distinction between the practice of law and equity or if purely procedural requirements governing an independent court action are satisfied. Because they often nullify the effect of arbitration as a speedy and inexpensive means of solving controversies, these procedural standards should be rejected. If an order denying a motion to compel arbitration of a controversy is unappealable, a party must wait until final judgment in a suit on the contract before he may appeal the court's ruling on his motion. Should the appellate court determine that the lower court's order denying the motion was erroneous and direct the parties to arbitrate, the time and expense of a trial have been wasted, and the purpose of the parties in employing an arbitration clause is thwarted. Similarly, an unappealable order compelling arbitration will waste the time and expense of an arbitration proceeding if the order is in error. An appellate decision that this order was incorrect requires the party who brought the original contract action to proceed with the original suit to secure any remedy. By binding the parties in any future action, ${ }^{26}$ an immediate right of appeal from an order denying or granting a motion to compel arbitration would eliminate any possibility of an unnecessary trial or arbitration proceeding.

The writ of mandamus has been used to establish appellate review over unappealable orders concerning arbitration. ${ }^{27}$ A lower court order compelling

23. Id. at 452; Gatliff Coal Co. v. Fox, 142 F.2d 876 (6th Cir. 1947) ; cf. Greisa v. Mutual Life Ins. Co., 165 Fed. 48 (8th Cir. 1908), cert. denied, 215 U.S. 600 (1909).

24. Baltimore Contractors, Inc. v. Bodinger, 348 U.S. 176 (1955); Turkish State Ry. Administration v. Vulcan Iron Works, 230 F.2d 108 (3d Cir. 1956); Wilson Bros. v. Textile Workers Union, CIO, 224 F.2d 176 (2d Cir.), cert. dented, 350 U.S. 834 (1955).

An order in admiralty granting or refusing a motion to stay the suit and compel arbitration is an unappealable interlocutory order because admiralty courts do not issue injunctions. See note 19 supra and accompanying text.

25. See cases cited note 24 supra.

Since the appealability of an order on motions to compel arbitration and to stay a suit will be based on whether a grant or denial of $\S 3$ is equivalent to an injunction, it may be advisable to make the motions separately when the original contract action is equitable and the decision on the motions thus unappealable. The court may consider the separate application for a motion compelling arbitration as an independent proceeding and thus the order on the motion a final judgment. See note 17 supra and accompanying text. A party is best assured of an appeal by moving to compel arbitration in an independent action before the other party initiates a suit on the contract dispute. See cases cited note 11 supra.

26. See cases cited note 44 infra (res judicata effect).

27. International Refugee Organization v. Republic S.S. Corp., 189 F.2d 858 (4th Cir. 
arbitration or staying a pending suit may be subjected to review by petition for mandamus to an appellate court and thus made appealable. ${ }^{28}$ Mandamus will issue to determine whether the inferior court has wrongfully abandoned jurisdiction over the dispute by this order. ${ }^{29}$ Similarly, the writ can be invoked to determine whether a lower court has extended its jurisdiction to a dispute which ought to be decided by an arbitration board when it denies a motion to compel arbitration or to stay. ${ }^{30}$ However, mandamus is of limited effectiveness in securing review of orders entered under sections 3 and 4 . It is used only sparingly and for "extraordinary" cases. ${ }^{31}$ Since its grant is entirely discretionary with the appellate tribunal, ${ }^{32}$ no certainty exists that the court will consider the writ appropriate in any particular proceeding.

A sufficient body of judicial theory is presently available in the interlocutory injunction and collateral order rules to permit appealability of arbitration orders in any procedural context. Since an order compelling arbitration specifically enforces an arbitration agreement and has the "substantial effect" of an interlocutory injunction order, ${ }^{33}$ it should be made appealable. Furthermore, courts have consistently allowed an immediate appeal from an order entered on a motion to stay an action at law pending arbitration. ${ }^{34}$ Since the stay prevents the parties from litigating the dispute, a remedy can be secured only through

1951). See suggestion for use of mandamus in Stathatos v. Arnold Bernstein S.S. Corp., 202 F.2d 525, 528 (2d Cir. 1953) (dissenting opinion).

Mandamus is one of the prerogative writs authorized by the All Writs Statute, 28 U.S.C. $\$ 1651$ (a) (1952). It is traditionally employed to confine an inferior court to the exercise of its prescribed jurisdiction or to compel the exercise of its authority. Roche v. Evaporated Milk Ass'n, 319 U.S. 21 (1943) ; Ex parte Peru, 318 U.S. 578 (1943). See, generally, Notes, 63 Yale L.J. 105 (1953), 50 Colvir. L. Rev. 1102 (1950).

28. International Refugee Organization v. Republic S.S. Corp., 189 F.2d 858 (4th Cir. 1951) (mandamus to compel dissolution of unappealable stay order pending arbitration).

29. Ibid. Courts have asserted mandamus will lie to review an order which would cause an unnecessary trial if erroneous. Ext parte Peterson, 253 U.S. 300 (1920) (order should be dealt with immediately before the parties are put to difficulty and expenses by a proceeding ultimately held to be a mistake); E.r parte Simons, 247 U.S. 231 (1918). The writ should thus be particularly useful to secure appealability of arbitration orders, since the wasted proceedings could otherwise easily occur. See text at note 26 supra.

Compare also the use of mandamus to review the following: McClellan v. Carland, 217 U.S. 268 (1910) (stay of proceedings); United States v. Kirkpatrick, 186 F.2d 393 (3d Cir. 1951) (reference to a master) ; Foster-Milburn Co. v. Knight, 181 F.2d 949 (2d Cir. 1950) (order transferring action); Bereslavsky v. Caffey, 161 F.2d 499 (2d Cir.), crt. denicd, 332 U.S. 770 (1947) (striking demand for jury trial).

30. Cf. Ford Motor Co. v. Ryan, 182 F.2d 329 (2d Cir. 1950) (denial of motion to transfer) ; Hazeltine Corp. v. Kirkpatrick, 165 F.2d 683 (3d Cir. 1948) (denial of motion asking for dismissal of action).

31. Ex parte Fahey, 332 U.S. 258 (1947). See Wolfson, Extraordinary Writs in the Sutpremi Coutrt Since Ex Parte Peru, 51 Colux, L. Rev. 977 (1951).

32. Roche v. Evaporated Milk Ass'n, 319 U.S. 21 (1943) ; Ex parte Peru, 318 U.S. 578 (1943).

33. See Baltimore Contractors, Inc. v. Bodinger, 348 U.S. 176, 185 (1955) (dissenting opinion).

34. See note 23 supra and accompanying text. 
arbitration. ${ }^{35}$ An order compelling arbitration is essentially like grant of a stay in that the court no longer retains jurisdiction over the controversy, even if no formal stay is issued..$^{36}$ Accordingly, orders compelling arbitration in a legal proceeding should be appealable. But since courts presently allow interlocutory appeals only from injunction decrees, both solutions depend on an expansion of the concept of injunction to include arbitration orders. ${ }^{37}$

Even if a court should interpret such orders as injunctions, the problem of possible wasted trials or arbitration proceedings would not be entirely solved. Appeal from an interlocutory injunction order is not mandatory. ${ }^{38}$ Nor is a decision on the motion to compel or stay res judicata. ${ }^{30}$ Thus, unless an appeal is taken immediately, the correctness of the court's order may still be reopened on appeal from a judgment enforcing the arbitration award or from a final judgment in the contract action. ${ }^{40}$ If the appellate court then declares the order erroneous, the trial or arbitration proceeding has again been wasted. Only when an appeal is taken from an interlocutory order will all unnecessary proceedings be avoided. The decision of the appellate court will operate as "law of the case" on the question of arbitrability of the dispute and will subsequently bind both it and the district court.41

The problem inherent in the permissive appealability of interlocutory injunction orders may be avoided by considering orders affecting arbitration as within the collateral order rule. A collateral order having a "final and irreparable" effect on the rights of a party is appealable since it completely disposes of a claimed right not included in the main cause of action. ${ }^{42}$ Because logically and practically severable from factual and legal issues crucial to resolution of a dispute, the decision whether a judicial or an arbitrational tribunal shall hear

35. See The Anaconda v. American Sugar Refining Co., 322 U.S. 42,45 (1944).

36. See note 14 supra.

37. For examples of courts' reluctance to expand appealable injunctive decrees, see, e.g., Baltimore Contractors v. Bodinger, 348 U.S. 176, 184-85 (1955); Morgantown v. Royal Ins. Co., 337 U.S. 254, 258 (1949); MOORE, ComMenTaRY oN THE U.S. JUDICIAL CODE 492-93 (1949).

38. Victor Talking Mach. Co. v. George, 105 F.2d 697 (3d Cir.), cert. denied, 308 U.S. 611 (1939) ; A. \& R. Realty Co. v. Northwestern Mut. Life Ins. Co., 95 F.2d 703 (8th Cir. 1938); see 6 MOORE § 54.09.

39. A decision on an interlocutory order is not res judicata. Merrian Co. v. Saalfied, 241 U.S. 22 (1916) ; Republic of China v. American Express Co., 190 F.2d 334 (2d Cir. 1951) ; Joseph T. Ryerson \& Son v. Bullard Mach. Tool Co., 79 F.2d 192 (2d Cir.), cert. denied, 296 U.S. 648 (1935).

40. Cf. cases cited note 39 supra.

41. See Messenger v. Anderson, 225 U.S. 436 (1912) ; In re Sanford Fork \& Tool Co., 160 U.S. 247 (1895); General Am. Life Ins. Co. v. Anderson, 156 F.2d 615 (6th Cir. 1946). An appellate court may disregard its own "law of the case" in extraordinary circumstances. Western States Mach. Co. v. S.S. Hepworth Co., 152 F.2d 79 (2d Cir. 1945). See, generally, Notes, 40 ColvM. L. Rev. 268 (1940), 62 HARv. L. Rev. 286 (1948), 5 Stan. L. Rev. 751 (1953).

42. Cohen v. Beneficial Industrial Loan Corp., 337 U.S. 541. (1949); see 6 Moore § 54.14; Underwood, Appeals in the Federal Practice from Collateral Ordcrs, 36 VA. L. REv. 731 (1950). 
a controversy should fall within this rule. ${ }^{43}$ The possible expense and loss of time may be regarded as irreparable injuries, particularly since they are the very dangers the parties attempted to avoid by contracting for arbitration. If arbitration orders are held appealable as collaterial orders, the decision will be a binding final judgment ${ }^{44}$ from which appeal must be taken, if at all, within the thirty days prescribed by statute. ${ }^{45}$ Should appeal from the order not be taken within this period, the question of arbitrability cannot be subsequently litigated.

A federal statute allowing appeals from a court order on a motion to compel arbitration or to stay a pending suit would provide the most satisfactory solution. The statute ${ }^{46}$ might read as follows :

"A court order granting or denying a motion entered pursuant to sections 3 or 4 of the Federal Arbitration Act is a final order and appealable. If the appeal is in bad faith in the opinion of the appellate court, appellant may be assessed costs, ${ }^{47}$ including attorney's fees."

Under the statute, costs of an appeal would be small : since the request for an order compelling arbitration or to stay is made by motion practice, the record probably would be short and inexpensive to print. The time required by the appeal would be justified in avoiding a wasted trial or arbitration proceeding. ${ }^{48}$

43. See Baltimore Contractors, Inc. v. Bodinger, 348 U.S. 176, 185 (1955) (dissenting opinion).

44. Once an issue is finally decided between parties to an action, that determination is binding in subsequent litigation in which the same matter is again in issue between the same parties. See Fishgold v. Sullivan Drydock \& Repair Corp., 328 U.S. 275 (1946) ; Heiser v. Woodruff, 327 U.S. 726, 735-36 (1946) ; Restatenrent, JudganeNts \$ 1 (1942); Cleary, Res Judicata Reexamined, 57 Y ALE L.J. 339 (1948).

45. FED. R. CIv. P. 73(a).

46. New York permits appeal of arbitration orders. N.Y. CIV. PRAC. ACT $§ 1467$. An order compelling arbitration is a final order and appealable. Hosiery Manufacturers Corp. v. Goldston, 238 N.Y. 22, 143 N.E. 779 (1924). See Cohen \& Karger, The Powers of the NEw York Court of Appeals \& 31 (rev. ed. 1952); Bruce, What Is a "Final Order" Under the New York Arbitration Law?, 4 ARB. J. 104 (1940); Fraenkel, Procedural Aspects of Arbitration, 83 U. PA. L. REv. 226 (1934).

47. See 28 U.S.C. $\$ 1912$ (1952), allowing prevailing party damages or costs of appeal.

In line with the statutory proposal outlined in text, the circuit courts could develop rules giving priority to appeals from arbitration orders. Similar procedures exist on petitions to mandamus lower courts. See 3D Cir. Rule 19; 6TH CIR. Rule 35; Note, 65 YALE L.J. 1057, 1066 n.49 (1956).

48. The median time for the disposition of a normal civil case terminated by trial was 14.6 months in 1955. Annual Report of the Proceedings of the Judicial CoNFERENCE of THE UNITED STATES 51 (1955). The total elapsed time from the initiation of an arbitration proceeding to award is approximately 3 months. Comment, 61 YALE L.J. 686, 699 (1952); Note, 61 HARv. L. REv. 1022 n.1 (1948). The median time from the filing of a complete record to the final disposition of a case submitted to federal courts of appeals in 1955 was 7.3 months. ANNuAL Report of the Proceedings of the Judicial CONFERENCE, supra at 53. Therefore, where appeal is allowed from an order denying arbitration and an appellate court finds this order erroneous, the total proceeding from initiation of the motion to compel arbitration through the appeal and subsequent arbitra- 
Use of arbitration as an expeditious method of settling civil controversies would thus be furthered and the present conflict between the final judgment policy of federal appellate procedure and the Arbitration .tct eliminater.

tion proceeding would be about somewhat over 10 months. This is almost a year less than the time a party would have to spend going through a trial and appeal if an erroneous order denying arbitration were not immediately appealable. Where an order compelling arbitration is unappealable and erroneous, the loss of time will amount to the three months or so spent in the arbitration proceeding. 